\title{
Santarém: o ponto de partida para 0 (ou de retorno) urbano utopia
}

\author{
Santarém: the starting (or returning) point to the urban-utopia
}

Taynara do Vale Gomes[a], Ana Cláudia Duarte Cardoso[a]

[a] Universidade Federal do Pará (UFPA), Belém, PA, Brasil

Como citar: Gomes, T. V., \& Cardoso, A. C. D. (2019). Santarém: o ponto de partida para o (ou de retorno) urbano utopia. urbe. Revista Brasileira de Gestão Urbana, 11, e20170219. https://doi.org/10.1590/2175-3369.011.001.A003

\section{Resumo}

Este artigo discute o progressivo descolamento observado entre cidade, urbano, rural e natureza em contexto amazônico. Partiu-se da geo-história, abordagem lefebvriana de análise da formação espacial, do sítio de Santarém (PA) e adjacências, para explicitar a natureza híbrida de um tecido urbano extensivo, formado por tipologias urbanas descontínuas (cidade e vilas), periurbanas (comunidades e assentamentos) e rurais (campo de soja, floresta e comunidades extrativistas), segundo arranjos socioespaciais herdeiros de diferentes matrizes culturais. A partir da revisão de literatura, da análise de cartografia histórica e de dados digitais, observa-se que o urbano, orientado por processos globais e pelo interesse econômico, nega e desestrutura territórios, nos quais a sociobiodiversidade e as práticas desenvolvidas ao longo dos séculos são portadoras de potencial reconciliação entre urbano e natureza, bem como valiosas em contexto de mudanças climáticas. O estudo detalha a análise para a mancha urbana da cidade de Santarém, assumida como um amálgama que espelha a diversidade socioespacial da região e que melhor ilustra a forma como a concepção hegemônica de cidade, aplicada ao urbano periférico amazônico, tem distanciado Santarém do potencial de expressar o urbano utopia, o qual será capaz de resgatar a indissociabilidade de pessoas, biodiversidade, solo e água, que já vem sendo manifestada há séculos na Amazônia.

Palavras-chave: Diversidade socioespacial. Santarém. Amazônia. Urbanização extensiva. Urbano utopia.

\section{Abstract}

This article discusses the progressive detachment observed between city, urban, rural and nature in the Amazonian context. We start from the geo-history, Lefebvrian's approach of the spatial formation analysis of Santarém's site and surroundings, to explain the hybrid nature of an extensive urban fabric, composed by discontinuous urban (city and village), peri-urban (communities and settlements), and rural (soybean, forest and extractive communities) typologies, according to socio-spatial arrangements from different cultural matrices. Findings based on literature review, analysis of historical cartography and digital data have shown that the urban, driven by global processes and by the economic interest, denies and de- 
structures territories, where socio-biodiversity and practices developed over the centuries, and carry a potential of reconciliation between urban and nature, valuable in the context of climate change. The study details the analysis of the urban fabric of the city of Santarém, considered an amalgam that mirrors the region's socio-spatial diversity, and which best illustrates how the hegemonic conception of the city. That, applied to a Amazonian peripheral urban, has distanced Santarém from its potential of expressing the urban utopia, which will be able to rescue the inseparability of people, biodiversity, soil and water already manifested for ages in the Amazon.

Keywords: Socio-spatial diversity. Santarém. Amazon. Extended urbanization. Urban utopia.

\section{Introdução}

Até o século XX, foi fácil entender a materialidade do urbano por meio da forma da cidade. Havia uma forte identificação entre estas duas manifestações: a compreensão do urbano como reverso do rural; e a cidade como uma espécie de antítese da natureza, como o espaço artificial (Monte-Mór, 2014). Sob essa perspectiva, um mosaico que entremeasse categorias (urbano, cidade, rural, natureza), como acontece em Santarém, seria algo incompreensível.

Apesar de Santarém ser herdeira de milênios de ocupação pela civilização Tapajônica do sítio em que se localiza (Roosevelt, 2009), a cidade não contou com atributos que a destacassem aos olhos dos formuladores de políticas públicas durante a fase de integração econômica e rodoviária da Amazônia brasileira, quando considerada do ponto de vista clássico sobre urbano/cidade, pois era destituída de estruturas excepcionalmente marcantes, capazes de expressar o poder que a cidade exercia sobre o campo, a exemplo de como se avaliava o poder do urbano em cidades no passado (ver Quadro 1). Toda a região era vista como agrária, marginalmente inserida na divisão do trabalho da sociedade industrial (Tavares, 2001), e, entre as típicas cidades ribeirinhas, só as duas metrópoles regionais eram reconhecidas como aglomerações importantes na região (Correa, 1987).

Quadro 1 - Estruturas marcantes de poder em cada tipo de cidade

\begin{tabular}{|c|c|}
\hline Tipo de cidade & Estrutura marcante \\
\hline Grega & Ágora e acrópole \\
\hline Burguesa & Praça do mercado e catedral \\
\hline Barroca & Monumentos e perspectivas cenográficas \\
\hline Industrial & Arranha-céu, centros empresariais e estruturas viárias \\
\hline
\end{tabular}

Fonte: Elaborado pelos autores (2017).

Contudo, as adições do passado colonial e das fases mais recentes geraram estruturas espaciais híbridas que se mantiveram imperceptíveis, até que a dissociação entre essas camadas se tornasse possível (por exemplo, urbano diferente de cidade, rural diferente de natural). Nesse sentido, este artigo apoia-se na formulação lefebvriana sobre o urbano, a qual destaca que a urbanização não seria consequência da industrialização, mas que esta seria uma etapa de um processo de transição da ausência de urbanização para o urbano puro (Lefebvre, 1999).

Apesar do cuidado com que as cidades foram modeladas no passado, segundo Lefebvre (1999) o ponto de inflexão do rural para o urbano não dependeria da materialidade da urbanização que é manifestada na cidade. O lugar do poder político e o lugar da produção seriam as verdadeiras chaves desse processo, e a explicação para produção de estruturas monumentais ou capazes de transpor séculos, como foi o caso da cidade antiga, estaria na necessidade de as elites expressarem simbolicamente seu poder sobre os espaços de produção, em regra destacando diferenças de classes e de vinculação a sociedades patriarcais (Soja, 2000).

Sob essa ótica, à medida que avançou a correspondência entre espaço de produção e espaço de poder e deixou de existir disputa de territórios, as estruturas físicas de forte poder simbólico tornaram-se restritas aos espaços de poder, admitindo o tratamento do espaço restante como periferia, normalmente 
compreendida como espaço de carência de serviços e recursos. No alvorecer do século XXI, Santarém apresenta claras evidências de sua subordinação ao modo de produção hegemônico, visto que novas tipologias espaciais e construtivas emergem na paisagem (Cardoso et al., 2017), circunscritas a espaços muito definidos destacados de uma morfologia que se sedimentou muito lentamente e que, ao ser ressignificada como periferia pelo urbano extensivo contemporâneo (Monte-Mór, 2014), apresenta-se como um laboratório instigante, no qual as permanências e as resistências se mostram como portadoras de uma fase futura, em que o urbano (ou a sociedade plenamente urbana) seria compreendido pela universalização do acesso a serviços e equipamentos, pelo compartilhamento do poder entre cidadãos e pela capacidade de apropriação da natureza sem causar sua destruição, ou seja, é uma fase em que a diversidade terá direito de existir, o urbano utopia (Monte-Mór, 2015).

Apoiado nesse debate, este artigo busca explicar a manifestação de diversidades dentro e fora (no espaço periurbano) da cidade de Santarém, assumindo que as resistências vinculadas a formas passadas (vilas, comunidades, floresta, rio) podem ser tomadas como embriões de novos arranjos, portadores de lições para o futuro que se espera alcançar.

Santarém, uma cidade Amazônica, sujeita a dinâmicas globais e que, apesar da aproximação com a monocultura de soja, ainda conta com forte presença de florestas em seu entorno, pode ser uma inspiração importante para o urbano utopia proposto por Monte-Mór (2015), que reconhece que, se há um processo de urbanização extensiva ${ }^{1}$, este deve ser necessariamente acompanhado por um processo de naturalização extensiva (ideia reversa que assume que o tecido urbano deva ser permeado pelos espaços não construídos, que suportam os fluxos, os ecossistemas, os ciclos naturais e também as atividades humanas que dependem dos recursos naturais). A justificativa para tal afirmação advém da capacidade de convivência com o meio físico, desenvolvida no decorrer de séculos e que viabilizou a manutenção da sociobiodiversidade do lugar, indicativas de invejável resiliência nesses tempos críticos do Antropoceno (Boff, 2011).

A estratégia para dar materialidade a esse debate, detectar e discriminar padrões e estruturas espaciais que sirvam de evidência sobre a coexistência das categorias inicialmente citadas (urbano, cidade, rural, natural) foi recuperar as ferramentas de análise da morfologia urbana ${ }^{2}$ e atualizá-las pelo uso de imagens de satélites, de camadas (shape files) de geoprocessamento e de resultado de observações, entrevistas e levantamentos realizados em pesquisas de campo de 2015, 2016 e 2017.

0 texto está estruturado em três partes: a primeira é dedicada a diferentes perspectivas do conceito de urbano a partir da ótica lefebvriana; a segunda faz uma narrativa do processo de formação do espaço da cidade de Santarém com uma abordagem da sua geo-história (Soja, 2000); e a terceira aborda a diversidade de formas e estratégias de apropriação do território por meio da comparação de atributos de morfologia urbana.

\section{O conceito de urbano sob diferentes perspectivas}

De acordo com o pensamento de Lefebvre (1999), no estágio da sociedade agrária o campo era dominado pela cidade política, e as derivações dessa relação passaram a se manifestar a partir dos conflitos entre categorias, tais como trabalho material e trabalho intelectual, ou produção e comércio. Durante esse primeiro estágio, a cidade era vista como um espaço não produtivo, mas seria o lugar que emanava o poder político e ideológico e determinava o uso do excedente produzido no campo. Seguindo a linha do tempo de conversão do espaço rural em urbano de Lefebvre (1999) (ver Figura 1), a sociedade

\footnotetext{
1 “[...] uma urbanização que se estende para além das cidades em redes que penetram virtualmente todos os espaços regionais integrandoos em malhas mundiais - [que] representa, assim, a forma socioespacial dominante que marca a sociedade capitalista de Estado contemporânea em suas diversas manifestações, desde o centro dinâmico do sistema capitalista até - e cada vez mais - às diversas periferias que se articulam dialeticamente em direção aos centros e subcentros e subsubcentros" (Monte-Mór, 1994, p. 171).

2 Segundo Oliveira (2018, p. 1), morfologia urbana é a ciência que estuda a forma física das cidades, os principais atores e os processos de transformação que moldam essa forma. Como campo de estudos, tem uma natureza multidisciplinar, beneficiando-se de diferentes disciplinas e "abordagens" dentro da mesma disciplina.
} 
agrária teria sido suplantada graças ao movimento voluntário de população rural em direção à cidade, pois esta, então percebida como lugar de civilização e urbanidade, passou a ser vista como um lugar com grande potencial articulador para o mercado. Essa migração fortaleceu a dominação da cidade sobre o campo e permitiu o surgimento de estruturas produtivas industriais nos arredores de cidade dos países do Norte (em função da mão de obra barata), dando início ao processo de transformação do espaço, do tempo e da força de trabalho em mercadoria (Lefebvre, 2008).

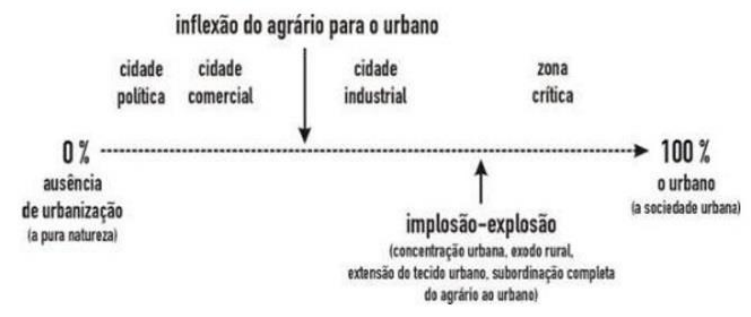

Figura 1 - Linha do tempo lefebvriana de transição do período de ausência de urbanização para urbanização completa da sociedade. Fonte: Lefebvre (1999, p. 27).

Esse passo viabilizou o ponto de inflexão da transformação do espaço da cidade, antes lugar do poder político e da festa, em espaço da produção, constituído a partir do objetivo fundamental de atender à produção industrial e à reprodução coletiva da força de trabalho. Desse ponto em diante, foi possível que a cidade (industrial) manifestasse um processo de implosão e explosão, em que a enorme concentração de riquezas, pessoas, atividades, instrumentos e pensamentos implode continuamente as estruturas existentes, enquanto surgem as periferias, os subúrbios, as residências secundárias e as cidades-satélite, em um movimento de explosão de um tecido urbano estruturado pelas novas infraestruturas de mobilidade (Lefebvre, 1999). No estágio atual, o avanço desse tecido urbano viabiliza a formação do urbano extensivo (Monte-Mór, 1994), também apresentado por Brenner \& Schmid (2015) como urbanização planetária, que extrapola completamente as cidades e distancia, cada vez mais, os centros de suas periferias.

Em que pese essa caracterização ter sido formulada assumindo a trajetória das sociedades industriais, ajuda a decifrar a transformação de outros territórios, absorvidos pela divisão internacional do trabalho como fontes de matéria-prima para sociedades industriais, como a Amazônia.

No decorrer das sucessivas colonizações que a região sofreu, a racionalidade urbano-industrial esteve subjacente desde a forma como os colonizadores portugueses definiram as condições de exploração extrativistas até o modo como o governo militar brasileiro estabeleceu as condições de integração nacional $^{3}$ (Becker, 2013).

Todavia, as políticas colonizadoras se superpuseram a um padrão de dispersão, que só recentemente tem sido compreendido. Pesquisas da arqueologia publicadas em Heckenberger (2016) e Neves (2015) indicam que a população da região antes da chegada dos europeus era apenas um pouco menor do que a existente hoje, mas caracterizada pela dispersão e pelo hábil manejo dos recursos naturais disponíveis, e que, para as sociedades indígenas que viviam na Amazônia, a produção das pessoas era mais importante do que a produção (ou o acúmulo) material (Heckenberger, 2005). Essa diferença em relação às sociedades ocidentais gerou formas de apropriação absolutamente diversas nas últimas décadas, enquanto indígenas foram dizimados, migrantes foram assentados, aglomerações foram transformadas de acordo com a compreensão contemporânea de formas e funções da cidade, bem como o território "rural", ocupado por antigos migrantes e caboclos, passou a ser disputado por atividades de caráter industrial (monocultura, extração mineral, exploração de madeira, geração de energia etc.).

\footnotetext{
${ }^{3}$ A exploração de recursos naturais na Era Pombalina só foi bem-sucedida graças à indução de vilas e pequenas cidades nas calhas dos grandes rios amazônicos e à miscigenação entre indígenas e portugueses. E as políticas de integração nacional e os grandes projetos federais só potencializaram a exploração de recursos naturais, urbanizando a região, por causa da transformação das cidades próximas aos grandes projetos e da criação de outras.
} 
A rapidez da transformação decorrente da globalização da economia fez com que o tecido urbano global assimilasse tais territórios, conectando-os aos centros globais de tomada de decisão e aos centros de produção industrial. Contudo, a condição secular de periferia gerou nas elites locais a expectativa de abrigar atividades industriais, mesmo que elas tenham no século XXI um significado completamente diferente daquele que teve no século XIX para as sociedades europeias (Hardt \& Negri, 2004). Esse desejo de seguir a trajetória de urbanização da civilização ocidental contribuiu para a desvalorização do conhecimento e das formações socioespaciais herdadas de outros séculos por elites e por políticas públicas, que, desde o governo militar, são orientadas por centros cada vez mais distantes (nacionais e globais).

0 atual estágio de urbanização da humanidade corresponde ao que Lefebvre (1999) chamou de zona crítica, isto é, o limiar da etapa que virá quando a fase urbana suplantar a Era Industrial. Ainda que o urbano pleno não seja realidade, já é uma possibilidade latente (ou uma expectativa) em sociedades pósindustriais que procuram desenvolver novos paradigmas, avançar em direção à universalização de direitos e da apropriação da natureza, tanto quanto avança a compreensão do contexto de mudanças climáticas desencadeado pelo homem, nessa breve era chamada de Antropoceno (Boff, 2011). Observase que algumas expectativas e alguns valores (humanização de escala territorial na cidade, redução de emissões de $\mathrm{CO}_{2}$, vitalidade e multifuncionalidade de espaços, contato direto com a natureza, desaceleração do ritmo cotidiano, maior importância dada ao valor de uso do que ao valor de troca) (Harvey, 2011; Hardt \& Negri, 2016) são semelhantes às formas de viver de comunidades e de grupos sociais que habitam a região de Santarém, herdeiros de povos nativos (caboclos, quilombolas, indígenas), os quais têm demonstrado enorme resiliência ${ }^{4}$ aos ciclos da natureza por séculos (senão milênios).

Curiosamente, na Amazônia, os valores pré-industriais dos caboclos e extrativistas estão mais alinhados com as expectativas das sociedades pós-industriais que oferecem melhores condições de vida às suas populações. Contudo, os modos de vida desses grupos estão ameaçados pela pressão do avanço da conversão da antiga Amazônia (agrária) em uma de base industrial do século XXI. Além disso, apesar da incorporação da região por um tecido urbano extensivo, já não há interesse na produção de cidades como ocorreu na Europa do século XIX; a viabilização de infraestrutura logística para a produção (ou para a exportação dos recursos naturais e grãos) é o suficiente. Dessa forma, a possibilidade de a cidade funcionar como espaço de emancipação e centro difusor de respeito à sociobiodiversidade é muito reduzida. A grande escala do tecido urbano extensivo e o foco na contribuição para a balança comercial colaboram para a invisibilização das dinâmicas que por séculos foram bem-sucedidas na região.

0 potencial de aproveitamento dos conhecimentos oriundos da diversidade da natureza para criar um novo urbano, que utilize a cidade como espaço de articulação das camadas urbana, rural e natural, vem sendo subjugado à lógica do espaço eficiente para o mercado e mal estruturado para o cotidiano das pessoas (Lefebvre, 1999). Além de não proporcionar benefícios aos grupos que não estão diretamente inseridos na dinâmica capitalista (ribeirinhos, extrativistas, quilombolas, indígenas, caboclos e trabalhadores não assalariados em geral), o paradigma industrial gerou na região disputa pelo controle da terra, contaminação de rios, alteração no regime hídrico, redução de biodiversidade e imposição do modo de vida urbano (industrial) para além das cidades, traduzindo-se em uma extensão dos meios de consumo coletivo, justificado pela percepção oficial como espaço "desocupado".

Monte-Mór (2006) aborda a urbanização e o urbano como o lócus privilegiado do consumo e da reprodução da força de trabalho e, portanto, como o lugar da possibilidade de reinvenção da vida coletiva. Dessa forma, supõe-se que a apresentação do espaço de Santarém como um mosaico de múltiplas tradições, em que a conversão não foi concluída, previna a completa destruição de identidades e de saberes, a alteração da base biofísica e favoreça a busca por soluções e padrões de urbanização diferentes a partir dos modos de vida já modificados, mas ainda não totalmente metabolizados pelo sistema urbano-industrial.

\footnotetext{
${ }^{4}$ Segundo Gonçalves (2017, p. 372), o termo "resiliência" permite diferentes definições, entre elas, "medida da persistência e capacidade dos sistemas para absorver mudanças e perturbações mantendo a população e a estrutura de relações"; ou a "capacidade de um sistema experienciar choques mantendo, essencialmente, a mesma função, estrutura, reações, e, portanto, preservando a identidade".
} 


\section{Uma geo-história para a região de Santarém}

Segundo Soja (2000), a geo-história é o estudo da dialética socioespacial inerente ao relacionamento entre homem e natureza, abordagem essa que expressa como as relações sociais se manifestam no espaço, estruturam-se e são condicionadas pelo território. Partindo desse princípio, este texto recupera o histórico de formação do território de Santarém para explicitar a importância dos diferentes processos sociais para a estruturação daquele espaço e para a produção da morfologia da cidade. A geo-história, segundo Soja (2000), explica a vida em sociedade a partir de fatores físico, biológico e social, e mostra como eles estão fortemente atrelados e condicionam o modo de vida das pessoas, propiciando a incorporação do bioma e dos modos de vida típicos da região.

A localização de Santarém em um rico território, no encontro do rio Tapajós com o rio Amazonas, em área de solo fértil, de floresta consolidada, com abundante biodiversidade e beleza cênica, boa conexão com outras aglomerações, explica os registros arqueológicos, que datam ocupações anteriores a 7 mil anos, por civilizações portadoras de dinâmicas urbanas, cultura própria, organização social e formação de redes. Apesar de oficialmente a cidade possuir 356 anos, desde sua fundação como vila portuguesa, Santarém pertence a um grupo de assentamentos humanos com profundas raízes pré-cabralinas, com área urbana que apresenta indícios de ser um espaço ocupado desde o século X (Roosevelt, 2009).

0 padrão de ocupação do território sempre foi de dispersão, com pequenas localidades distribuídas ao longo das calhas de rio, acompanhando as suas várzeas, áreas mais propícias ao plantio e que permitiam fácil deslocamento (Heckenberger, 2005).

0 mito de que a região era despovoada e dispunha de recursos infinitos (Loureiro, 2002) justificou o direcionamento de migrantes para a região (nordestinos refugiados da grande seca de 1915; assentados rurais da região Sul na década de 1970; trabalhadores para as obras dos projetos federais dos PNDs e do Polamazônia). Houve o crescimento de cidades, vilas, fazendas e estruturas produtivas, agora conectadas também por estradas, e a reestruturação da antiga rede urbana de padrão dendrítico (baseada nos rios), expandindo a cidade de Santarém em dois principais vetores: o rio e a penetração do território (ver Figura 2).
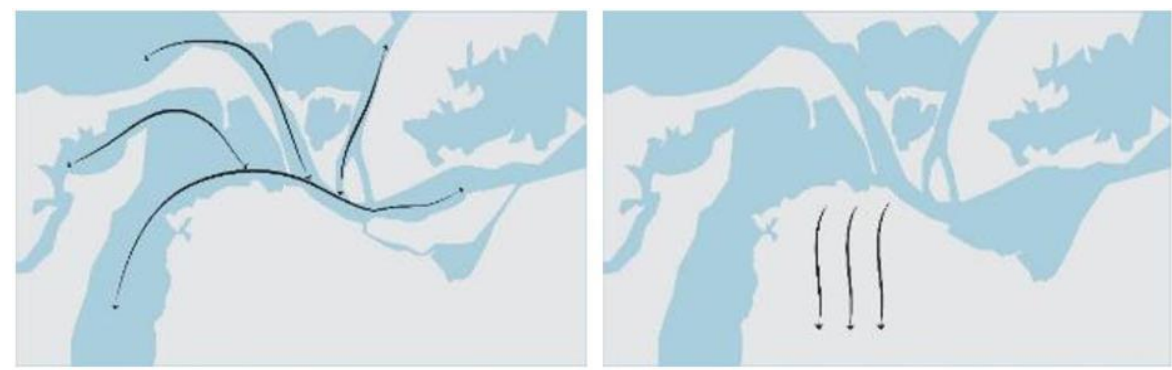

Figura 2 - Vetores de ocupação do teritório: margem do rio e penetração. Fonte: Elaborada pelos autores (2017).

Santarém reafirmou sua importância regional a partir do acúmulo de novas funções e destacou-se como polo regional segundo a lógica urbano-industrial. A consolidação da cidade no período colonial e o seu fortalecimento no decorrer do século XX, sob a hegemonia capitalista, são bem ilustrativas do fenômeno apresentado por Becker (1998) de urbanização da floresta na década de 1990.

Essa trajetória de urbanização da floresta invisibilizou a importância do sítio onde a cidade foi implantada como suporte ao modo de vida harmônico com a natureza (Roosevelt, 1992). Entretanto, essa mesma resiliência do modo de vida tradicional permitiu a resistência às pressões externas e a conquista de apoio em setores governamentais e em organizações não governamentais atuantes na área ambiental e agrária, que, articulados à população local, viabilizaram novas institucionalidades: formalizaram a presença de unidades de conservação e tipologias de assentamento rural (agroextrativistas) nos municípios de Santarém e de Belterra, que contribuem para a composição de um ambiente periurbano fortemente vinculado à floresta e às práticas tradicionais (Reserva Extrativista do Arapiuns, Floresta 
Nacional do Tapajós, Projeto de Assentamento Agroextrativista Eixo Forte, entre outras demarcações realizadas pelo Incra e Interpa).

A cidade se distinguiu do amálgama circundante, como a manifestação da fase urbano-industrial capitalista, à medida que conjuntos habitacionais e instalações portuárias, aeroportuárias e rodoviárias foram implantados a partir dos anos de 1970 e reestruturaram sua malha urbana. No século XXI, a obrigatoriedade de elaboração de um plano diretor para o município permitiu que, em 2006, uma extensa área, com raio de cerca de $30 \mathrm{~km}$, fosse reservada para expansão urbana, incluindo completamente o PAE Eixo Forte, por exemplo, assim como inúmeras vilas seculares. Essa medida distinguiu um espaço que posteriormente se tornou metropolitano (Pará, 2012), alcançando as cidades de Belterra e de Mojuí dos Campos, sedes de municípios desmembrados de Santarém. As duas cidades e a miríade de vilas seculares foram assimiladas no novo arranjo metropolitano como periferia da cidade-polo.

Na escala da cidade, Santarém foi o resultado do amálgama de assentamentos gerados por matrizes indígena, portuguesa e quilombola. Seus bairros mais afastados tiveram origem a partir de comunidades vernáculas, seguindo a caracterização espacial apresentada no Quadro 2.0 novo arranjo regional repete esse mesmo processo, por meio da combinação entre infraestrutura logística, mudança do uso da terra e da ressignificação das pequenas cidades de Belterra e de Mojuí dos Campos e das vilas existentes como "bairros distantes" da cidade. Um tecido urbano esgarçado com enclaves de tipologias contemporâneas e gradativa precarização de estruturas tradicionais para liberação das terras que ocupam novos usos e novas formas de produção (desde a monocultura da soja até os novos loteamentos que convertem floresta secundária em cidade). Assim como na formação da mancha urbana da cidade de Santarém, a acomodação das diversas matrizes esteve subordinada à hegemonia portuguesa - atualmente, o tecido urbano estendido de Santarém é subordinado à hegemonia dos setores produtivos capitalistas. Os registros historiográficos (mapas históricos) disponíveis em Muniz (1904) foram associados a shape files, que contêm informações gráficas e alfanuméricas sobre o sítio (topografia) e a malha contemporânea (ruas), e também a leituras de bandas de imagens de satélite Rapid Eye para o ano de 2015, para captura das massas verdes, de modo a permitir a ampliação da resolução dessa análise.

Quadro 2 - Caracterização das matrizes de ocupação do território

\section{DIFERENTES MATRIZES DE OCUPAÇÃO DE TERRITÓRIO}

Observa-se que, desde a metade do século XVII, com a chegada dos portugueses, a ocupação do território passou a assimilar influências portuguesa e quilombola sobre a matriz originalmente indígena, que, dado o seu sucesso histórico, influenciou o posicionamento das demais matrizes entre a floresta e o rio.

INDÍGENA

A forma como o território indígena estrutura as tipologias habitacionais, os espaços de vivências, de rituais a partir de uma concepção de coletividade (sem individualização) e da transitoriedade (sujeita ao reposicionamento conforme a disponibilidade de alimento) é menos agressiva e estabeleceu uma relação de interdependência com o meio (Pereira, 2016).

\section{QUILOMBOLA}

A matriz quilombola foi criada pela mistura da matriz africana com a indígena, também muito sensível às imposições da natureza e à disponibilidade de seus recursos (rios e floresta), mas com uma tendência de maior aglomeração das casas que a indígena, também sem uma organização espacial por sistema de ruas e quadras (Weimer, 2014).

\section{PORTUGUESA}

A introdução da matriz portuguesa, colonizadora abrangeu desde a apropriação do sítio indígena na margem do rio Tapajós, o posicionamento do assentamento paralelo ao rio, ao longo de ruas definidas pelos sobrados portugueses, com lotes individualizados, a apropriação do rio como vetor de escoamento da produção e mobilidade da população (visão logística) (Weimer, 2012). Os portugueses reproduziram em Santarém, mesmo que em pequena escala, um padrão de urbanização típico europeu, o qual, já no século XVIII, racionalizava o uso da terra com ruas em sistema de grelha, quadras pequenas e lotes estreitos, com centralidade definida pela presença de igrejas, prédios públicos e largos. 


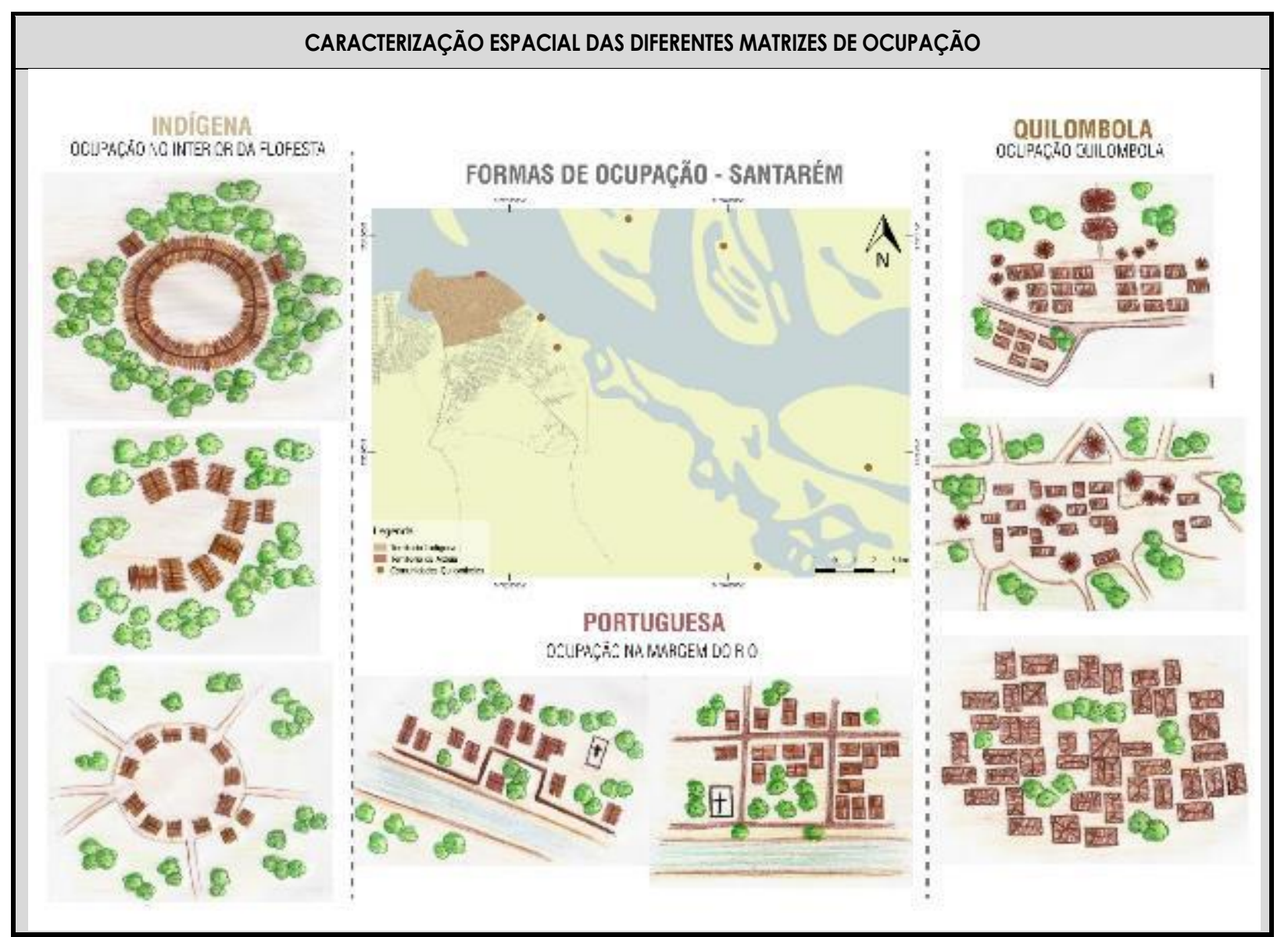

Fonte: Elaborado pelos autores com base em Weimer (2012).

A compreensão de como ocorreu a consolidação da mancha urbana da cidade de Santarém ajuda a ilustrar a subordinação histórica de diversas matrizes a uma diretriz oficial. 0 retorno à historiografia indica que a expansão da cidade sobre o território indígena na fase colonial ocorreu pela expulsão dos índios para a floresta e pela estruturação do bairro da Aldeia. Posteriormente, no século XIX, a expansão do ciclo da borracha e o fortalecimento da cidade no circuito produtivo foram reconhecidos por meio da proposta de um plano de alinhamento para a expansão urbana no espaço delimitado pela légua patrimonial da cidade, em atendimento às determinações da Lei de Terras de 1850 (Muniz, 1904; Cardoso \& Ventura, 2013).

Esse plano de alinhamento mudou a escala da cidade, a proporção das quadras, a largura das ruas, ignorou a relação de dependência da cidade com o rio e a floresta, reproduzindo o esquema de ruas e praças europeu. A abrangência do plano era tão grande quando comparada ao que existia na época, que apenas um século depois a mancha urbana preencheu a área prevista para o projeto. Apesar da racionalidade europeia ter sido colocada tão claramente, não houve meios para garantir a execução fiel do plano. 0 sistema de ruas foi simplificado e as praças foram suprimidas, o que permitiu adaptações às influências e aos saberes dos povos que já estavam consolidados no lugar, ainda que apenas de forma tácita (sem compreensão formal que alguns elementos do plano suprimidos eram compensados pelo entrelaçamento entre espaço construído e natureza) (ver Figura 3). Nessa fase mercantil do capitalismo, a estratégia do aviamento era desenhada de tal forma que todo o excedente da produção escoava para a metrópole, onde estava a concentração de renda (Ventura, 2012). A escassez de recursos para investimento na cidade e o isolamento de Santarém, possivelmente, contaram a favor das adaptações. 

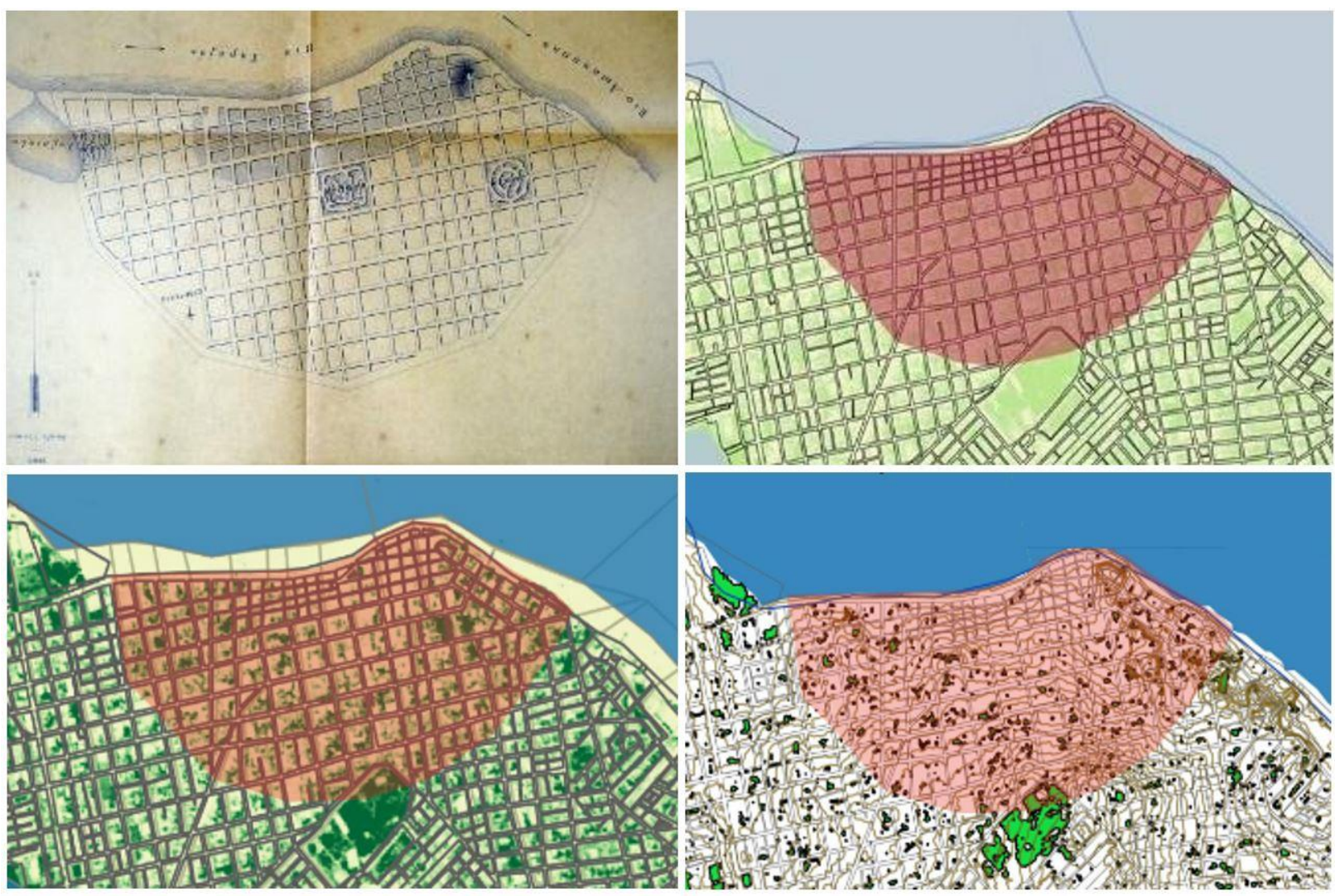

Figura 3 - Esquerda topo: plano original de 1850; direita topo: sistema de ruas efetivamente implantado (observar: quadras menores próximo ao rio, quadras maiores na expansão, supressão das praças e alteração do traçado nas bordas); esquerda abaixo: padrão de distribuição de vegetação no miolo das quadras maiores; direita abaixo: adaptação da malha ao relevo. Fonte: Elaborada pelos autores com base em Muniz (1904), Brasil (2015) e Santarém (2015).

Outra fase de mudanças significativas no padrão de expansão da mancha urbana da cidade ocorreu a partir dos anos de 1960, quando foram concebidos e implantados os planos de integração nacional. Novos fluxos migratórios foram direcionados para a região, sob novas condições de assentamento (reforma agrária), e financiados pela Superintendência de Desenvolvimento da Amazônia (SUDAM), em paralelo à implantação de grandes projetos de infraestrutura logística (porto, rodovia, aeroporto, hidrelétrica). 0 recuo de investimentos ocorrido após a elevação dos juros pós-crise do petróleo (Araújo, 2000) deixou assentados sem assistência e obras inacabadas, desencadeando um processo de transferência do contingente populacional atraído para ações de caráter agrário e extrativo para as cidades. A partir dos anos de 1980, o processo de periferização passou a atingir a capital e depois as cidades mais importantes do Pará, como era o caso de Santarém (Becker, 1998; Costa, 2014). Nesse período, uma nova estratégia da acumulação foi estabelecida, a qual ressignificou a terra pelo seu valor de troca e também a produção da cidade. A partir de então, a organização da cidade, por meio de um plano de alinhamento, deixou de ter importância, e as novas prioridades passaram a ser os elementos de infraestrutura necessários para o escoamento da produção do agronegócio e da extração mineral inseridos na cidade. A expansão de Santarém, observada na Figura 4, passou a ser definida pelas novas rodovias de acesso à hidrelétrica de Curuá-Una, ao aeroporto e à rodovia BR-163. Tais dinâmicas não pensam na cidade porque não precisam dela; são comandadas por centros mais distantes articulados pelo urbano extensivo. Nessa lógica, a cidade próxima ao local de produção não precisa ser estruturada, mas apenas oferecer o suporte mínimo para a função de ponto de controle. Assim, os espaços que antes abrigavam outros modos de vida que dependiam da terra tornam-se invisíveis e incompreendidos e passam a ser interpretados como a periferia precária da cidade capitalista. 


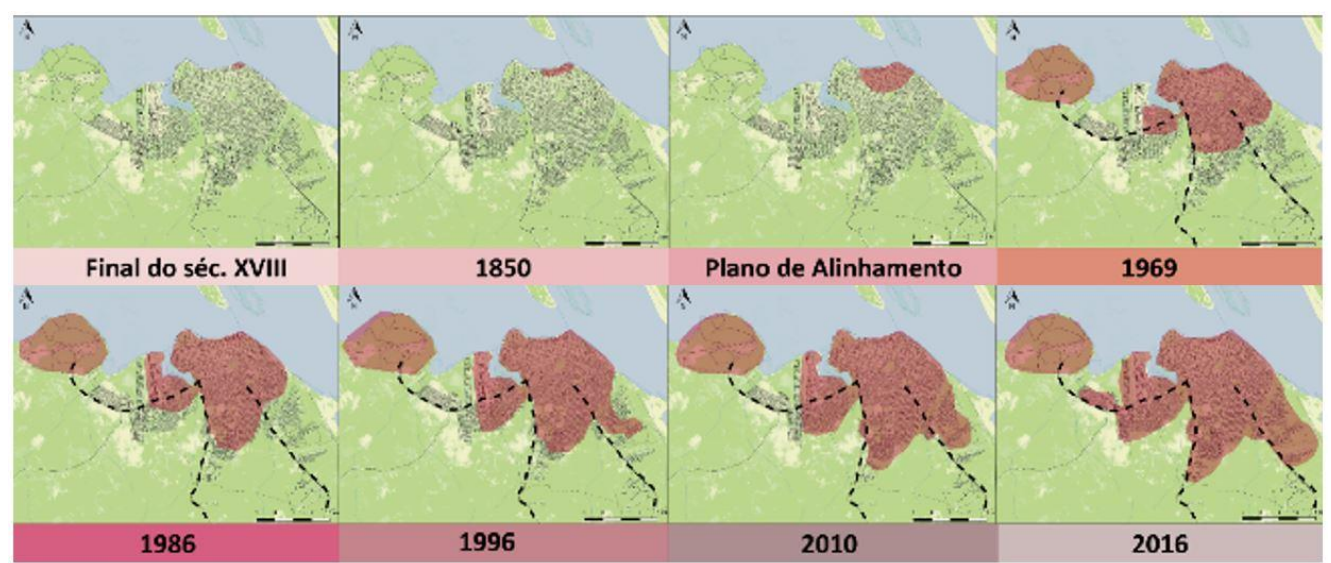

Figura 4 - Linha do tempo apresentando a evolução da mancha urbana de Santarém, com destaque para as rodovias principais. Fonte: Elaborada pelos autores com base no Google Earth (2017).

\section{A cidade: diversidade de formas e estratégias de apropriação do espaço}

0 relacionamento histórico entre urbano e cidade em Santarém justifica o detalhamento da materialidade da cidade a partir da observação da variação dos seus elementos morfológicos. A manifestação dos processos de "implosão" e de "explosão" em Santarém explicita as camadas de contradições e as formas de resistência observáveis na realidade cotidiana. Desse ponto em diante, a materialidade do tecido urbano é investigada por meio da sua decomposição em camadas, resultantes de um processo histórico de formação, por meio da sucessão de diferentes fases, que claramente correspondem a períodos morfológicos. 0 Quadro 3 apresenta o foco e as ferramentas de análises de diferentes escolas morfológicas que, embora sejam oriundas de contextos muito diferentes, oferecem meios para uma melhor caracterização do mosaico em que se transformou a cidade amazônica, assimilada pelas dinâmicas econômicas contemporâneas.

Quadro 3 - Principais contribuições dos estudos clássicos de morfologia urbana como ferramenta de análise dos processos espaciais

\section{CONTRIBUIÇÕES OFERECIDAS PELA MORFOLOGIA URBANA}

Segundo Gimmler \& Costa (2016), a grande contribuição oferecida pela morfologia urbana é a possibilidade de ler a paisagem a partir da reconstituição do processo pelo qual as cidades se formaram e se transformaram. Dessa forma, os estudos morfológicos auxiliam nas análises a partir da forma física da cidade e sua variação em função do tempo, e seu estudo permite a compreensão da formação e da estrutura urbana atual da cidade. Gimmler \& Costa (2016) afirmam que as cidades se constituem a partir de camadas que representam cada período de tempo e que, sobrepostas, formam o ambiente da cidade, indicando valores específicos associados a determinado momento da história. Os autores afirmam também que a forma urbana é reflexo das ações humanas, orientadas por aspectos sociais, políticos, econômicos e culturais, concluindo, assim, que a forma urbana é a materialização de uma construção social que reflete a cultura de seus habitantes (Gimmler \& Costa, 2016).

Nesse sentido, os estudos morfológicos se dividem classicamente em duas escolas: a escola inglesa, baseada na obra de Conzen $(1960,1988,2009)$, e a escola italiana, baseada na obra de Muratori $(1963,1967)$.

ESCOLA INGLESA

ESCOLA ITALIANA

- Tem como base a evolução urbana e analisa a cidade a partir da escala ampliada e sucessivamente vai reduzindo para observar os tecidos e os lotes.

- Divisão da paisagem urbana em três categorias: plano de cidade, tecido edificado e uso do solo.

- Processo de desenvolvimento urbano: cintura periférica, região morfológica e ciclo de parcela burguesa.

- Baseia-se no processo tipológico e faz o caminho inverso da inglesa, começando a análise pela edificação e depois vai ampliando os tecidos até chegar à escala do território.

- Conceitos-chave: tipo, tipologia, estrutura, tecido, série.

- Principal característica é a análise do processo tipológico. 


\section{SÍNTESE DAS CATEGORIAS PARA APLICAÇÃO NO TRABALHO}

Devido às limitações de contexto, foram selecionados conceitos-chave de ambas as escolas para orientar conceitualmente este trabalho e definir as ferramentas de análise espacial. Partiu-se da divisão da paisagem urbana elaborada por Conzen (1960), que estabelece três categorias (plano de cidade, tecido edificado e uso do solo) para caracterizar o processo de desenvolvimento urbano de Santarém, tais como a cintura periférica ${ }^{5}$ e a região morfológica ${ }^{6}$. A ampliação da resolução da análise conta com melhor suporte das categorias criadas por Muratori (1963) à análise do tecido urbano e das suas unidades morfológicas: sistemas de ruas, quadras, lotes e edificações.

\section{AVANÇO DOS ESTUDOS MORFOLÓGICOS}

Outras escolas foram estruturadas posteriormente em demais países (Moudon, 1997), e, de modo geral, tais estudos morfológicos servem como suporte para o entendimento da paisagem urbana e sua estrutura, pois estudam a forma da cidade, suas características exteriores, físicas e sua evolução no tempo (Lamas, 2004). Segundo Lamas (2004), os estudos da morfologia procuram entender os momentos de produção do espaço urbano e identificam esses mesmos momentos e suas inter-relações por meio não só do conjunto de fenômenos sociais e econômicos, mas também dos elementos que compõem a forma física da cidade.

Fonte: Elaborado pelos autores (2017).

Os registros das formas de apropriação social de Santarém, nos diferentes momentos de colonização ou ciclos de migração, expressam o somatório de relações observadas entre os elementos que constituem a estrutura espacial da cidade e as condições históricas, sociais, econômicas e políticas da sociedade que a produziu; dessa relação, surgiu um habitat responsivo a essas diferentes culturas.

Quando a mancha urbana da cidade cresceu, os limites naturais (rio e floresta) que funcionavam como obstáculo a essa expansão, uma vez extrapolados, constituíram cinturas periféricas e iniciaram a marcação das regiões morfológicas da cidade, geradas por combinações diferenciadas de elementos morfológicos (arruamento, quadras, lotes, áreas verdes) (ver Figura 5). A manutenção desses limites naturais por séculos demonstra a sua relevância para o cotidiano da vida das pessoas e a preservação da herança de parte da população local da interdependência com a natureza (suporte para o lazer, a sociabilidade e a produção extrativista e familiar), não reconhecida como relevantes pela fase urbanoindustrial do capitalismo.
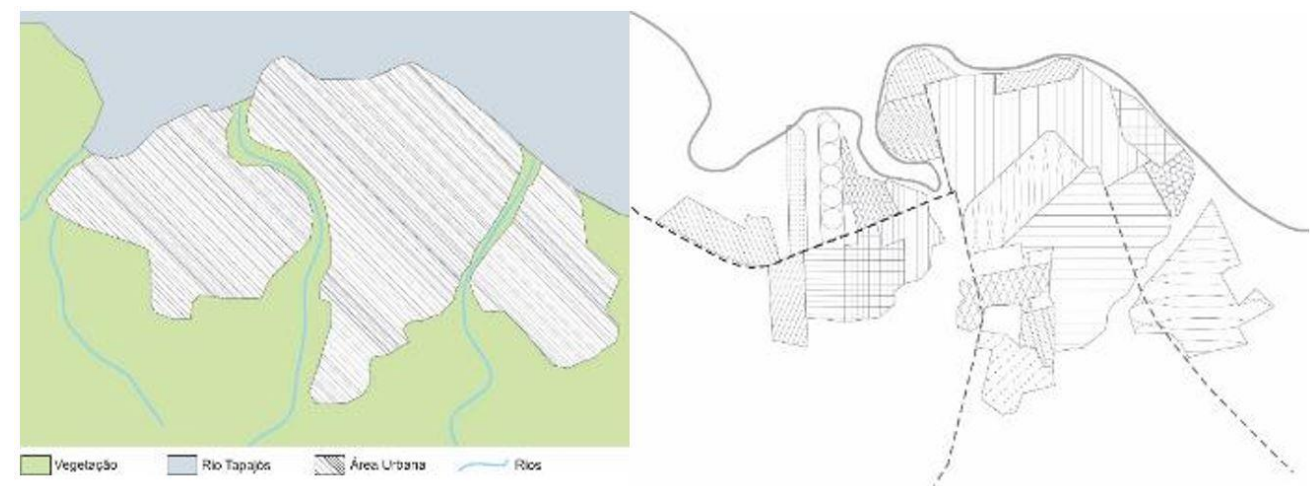

Figura 5 - Esquema de representação dos limites naturais que servem como barreiras para expansão urbana (à esquerda) e esquema de regiões morfológicas (à direita). Fonte: Elaborada pelos autores (2017).

A localização e a proximidade com o rio foram fatores determinantes para a estruturação do espaço de Santarém, pois, à medida que a malha urbana se afasta do rio, as características mudam. Os recortes propostos na Figura 6 caracterizam diferentes processos de formação e de apropriação, evidenciando os períodos de urbanização e o que estava na "agenda" prioritária em cada momento.

\footnotetext{
${ }^{5}$ Gimmler \& Costa (2016) conceituam cintura periférica como a franja urbana que se forma durante o período em que a área construída da cidade está em fase de consolidação. Essa área, geralmente, inclui vazios urbanos, áreas verdes, parques, vegetação abundante e pode servir como barreira para a expansão urbana.

${ }^{6}$ Região morfológica é uma área que conta com unidade na sua forma e se distingue das áreas envolventes (Gimmler \& Costa, 2016).
} 


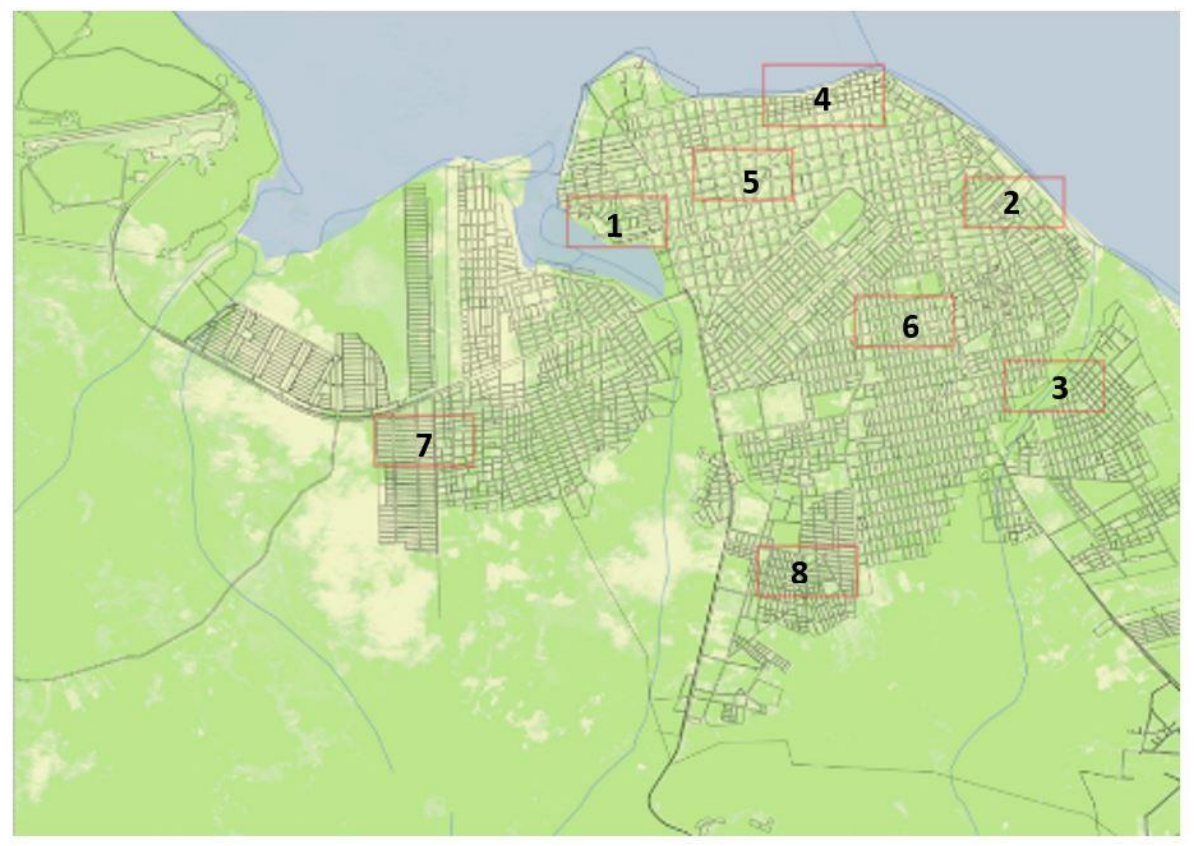

Figura 6 - Localização dos oito recortes selecionados para análise. Fonte: Elaborada pelos autores com base no Google Earth (2017).

A sequência dos recortes abrange áreas produzidas segundo matrizes portuguesa, indígena e quilombola, e as alterações recentes identificam os conflitos decorrentes do desvanecimento da matriz tradicional. A matriz hegemônica contemporânea intensificou a "modernização" da cidade, com a implantação (e o posicionamento) de uma nova escala de empreendimentos com novos usos típicos da fase de financeirização capitalista (shopping center, conjuntos habitacionais, loteamentos e condomínios), criando arranjos espaciais completamente novos.

As Figuras 7, 8 e 9 apresentam um comparativo da morfologia dos recortes selecionados na Figura 6. Sistemas de ruas, proporção de quadras e áreas livres/verdes são comparados em todos os recortes, de modo a demonstrar como as categorias geradas pela difusão da fase urbano-industrial - formal, informal e tradicional - são relativas nesse contexto.

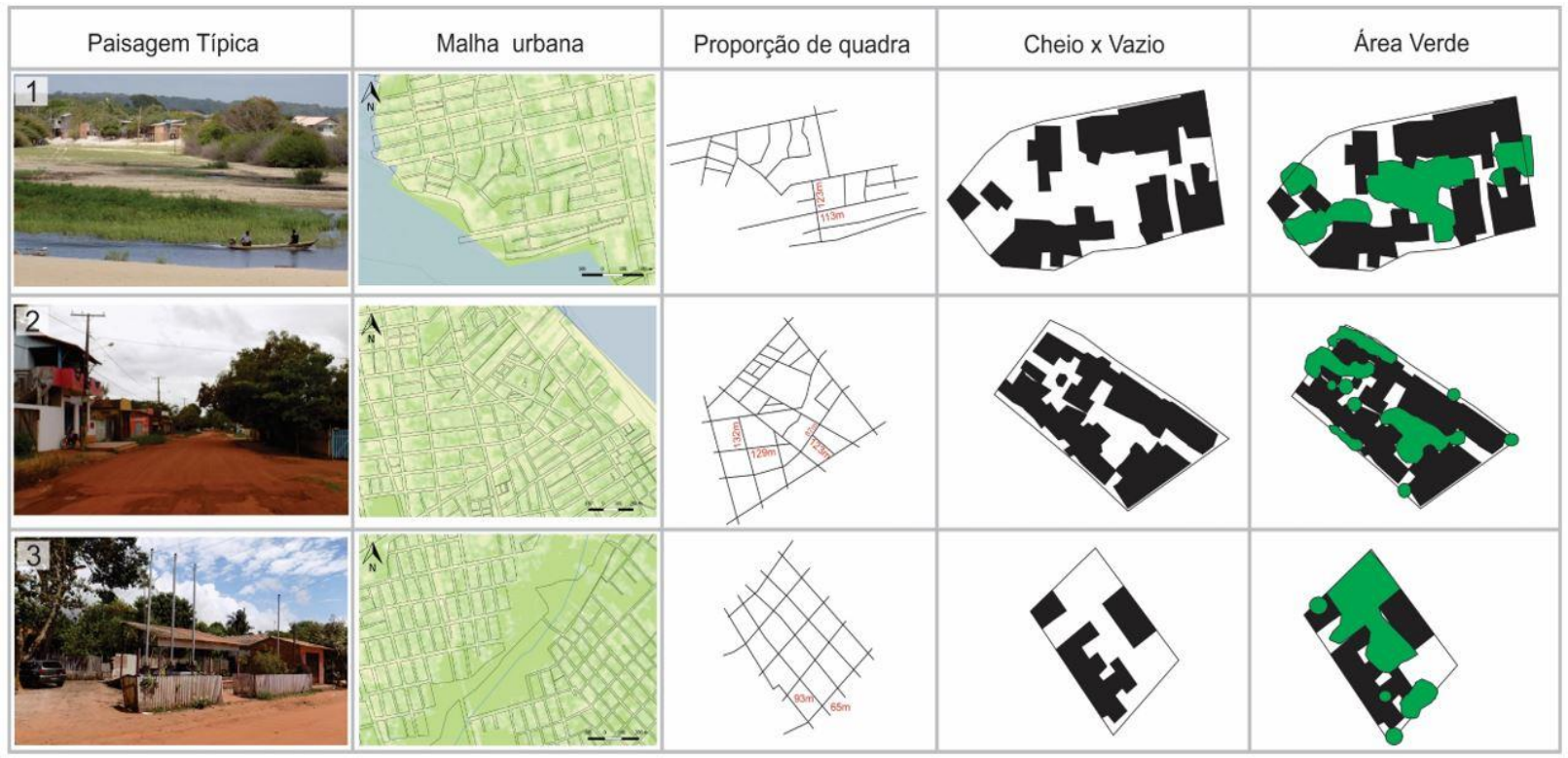

Figura 7 - Comparação da morfologia em diferentes recortes da cidade (áreas tradicionais). Fonte: Elaborada pelos autores (2017). 


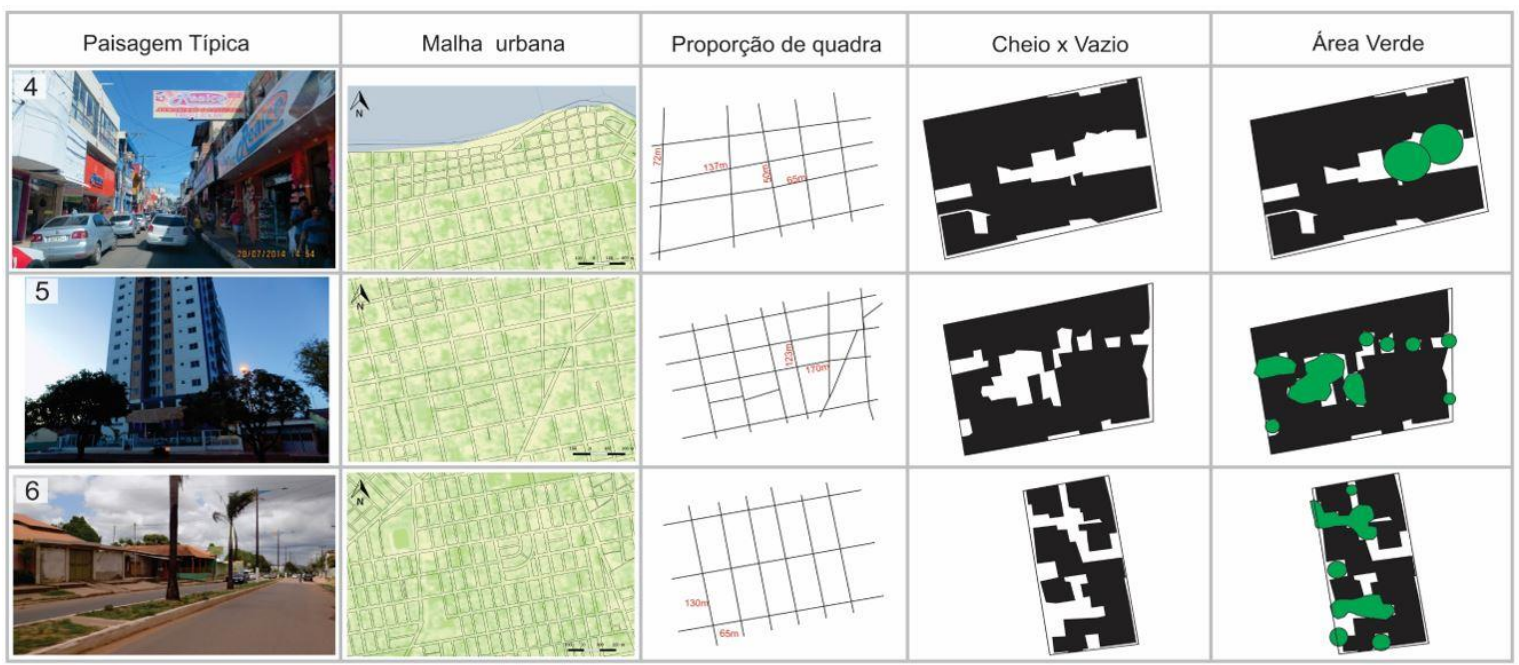

Figura 8 - Comparação da morfologia em diferentes recortes da cidade (áreas centrais). Fonte: Elaborada pelos autores (2017).

\begin{tabular}{|c|c|c|c|c|}
\hline \multicolumn{1}{|c|}{ Paisagem Típica } & Malha urbana & Proporção de quadra & Cheio $\times$ Vazio & Área Verde \\
\hline 7 & & & \\
\hline
\end{tabular}

Figura 9 - Comparação da morfologia em diferentes recortes da cidade (áreas periféricas). Fonte: Elaborada pelos autores (2017).

A distância da orla consolidada da cidade pode indicar localização mais periférica, sob o aspecto formal-informal, mas, na prática, a produção associada à informalidade segue a possibilidade de maior aproximação do modo de vida tradicional (recortes 1, 2 e 3 da Figura 6). Nessas áreas, ainda existem comunidades que são pautadas pelos ritmos da natureza e pela escala humana, que encontram facilidade de compor a renda com atividades ligadas ao extrativismo ou ao turismo ecológico; são áreas não planejadas onde o traçado das ruas é deformado para se adaptar ao sítio e onde ocorre maior presença de vegetação no miolo de quadra, indicando a possibilidade de uso dos quintais, como pomar, espaço de produção de ervas e alimento, ou simplesmente como espaço de arrefecimento do calor.

Nos recortes inseridos na área central (recortes 4, 5 e 6 da Figura 6), porção que corresponde ao centro histórico da cidade e ao antigo plano de alinhamento, a condição de infraestrutura é melhor, o sistema de ruas é regular, com quadras maiores, há maior adensamento construtivo, a acessibilidade dá preferência ao automóvel, e a vegetação é mais rara, contida no interior da quadra; nas demais áreas (fora do centro), o adensamento construtivo é relativamente menor, com maior permeabilidade dentro das quadras, mais vegetação no miolo e nas faces de quadra, e escala construtiva mais amigável ao pedestre.

0 recorte 7 da Figura 6 indica uma tipologia originária nos anos de 1970, o conjunto de habitação popular, o qual voltou a ser utilizado recentemente no programa habitacional Minha Casa, Minha Vida e "chegou" à cidade com 3.500 unidades, mas que não dialoga com a natureza, visto que as dimensões de lote e quadra são menores, pautadas pela racionalidade da produção de habitação em massa, sem considerar outras funções relativamente comuns do lote individualizado (moradia, produção, controle ambiental). 0 recorte 8 da Figura 6 apresenta uma área que surge de forma espontânea a partir do processo de periferização da cidade e, atualmente, já está em fase de consolidação; apesar do caráter popular, há quadras e lotes maiores que no conjunto habitacional e maior presença de vegetação. 
Os recortes de Santarém apresentados ilustram conflitos e dinâmicas socioeconômicas presentes no território. À medida que a cidade "explodiu" e sua mancha urbana integrou áreas (comunidades) antes isoladas, uma malha fragmentada e dispersa foi constituída. Por outro lado, a área que antes correspondia ao centro expandido da cidade começou a sofrer um processo de "implosão" devido tanto à introdução dos elementos de suporte à exportação de grãos (estrada, porto, área tomada pelo estacionamento de carretas) e de eliminação de formas históricas de ocupação (praia, casario) quanto à implantação de edifícios de até 30 andares nas ruas paralelas à beira do rio (ver Figuras 10 e 11).

0 padrão atual da expansão da área formal da cidade reinterpreta a margem do rio, substituindo a multifuncionalidade histórica por funcionalidades definidas para a produção (porto) ou para o consumo (orla de bares e restaurantes). Para promover essa metamorfose da cidade ribeirinha em cópia de cidades pós-industriais, tal sociedade destrói os espaços de subsistência de grupos sociais que não foram nem serão incluídos às novas dinâmicas econômicas (produção de soja e extração de madeira). Contudo, a eliminação dessa diversidade social implica perda do registro de como pode ser o relacionamento equilibrado com a natureza, de manutenção da várzea do rio, utilizada para produção de alimentos, lazer e refúgio de biodiversidade.

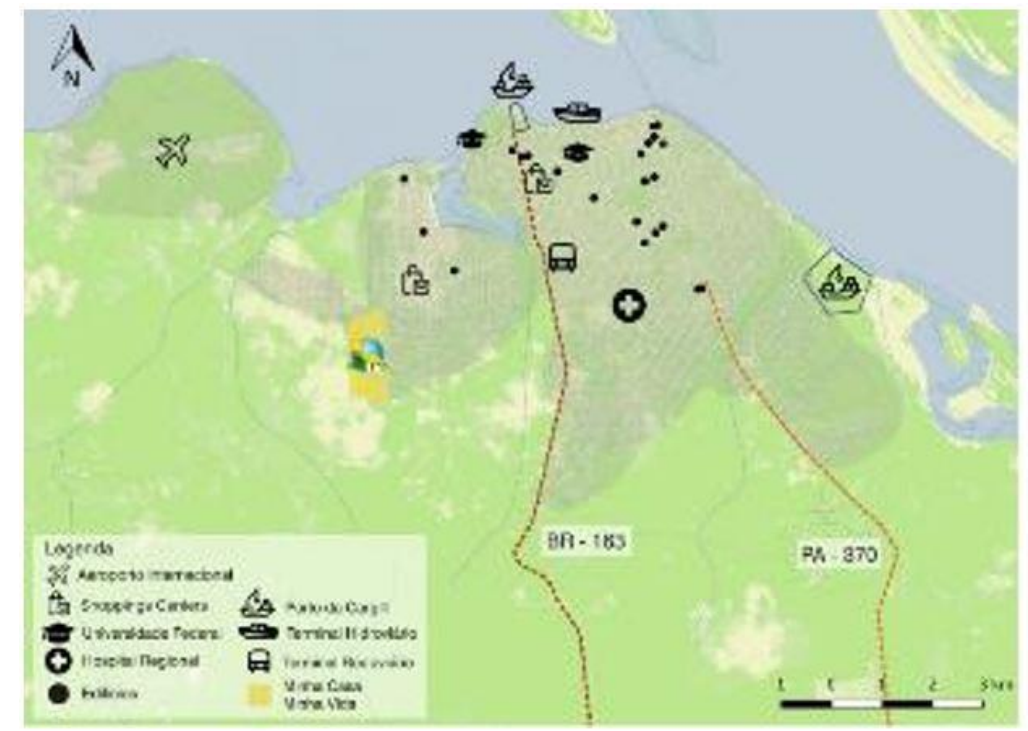

Figura 10 - Infraestrutura (logística) e grandes equipamentos que estruturam a cidade. Fonte: Elaborada pelos autores com base na pesquisa de campo (2017) e no Google Earth (2017).

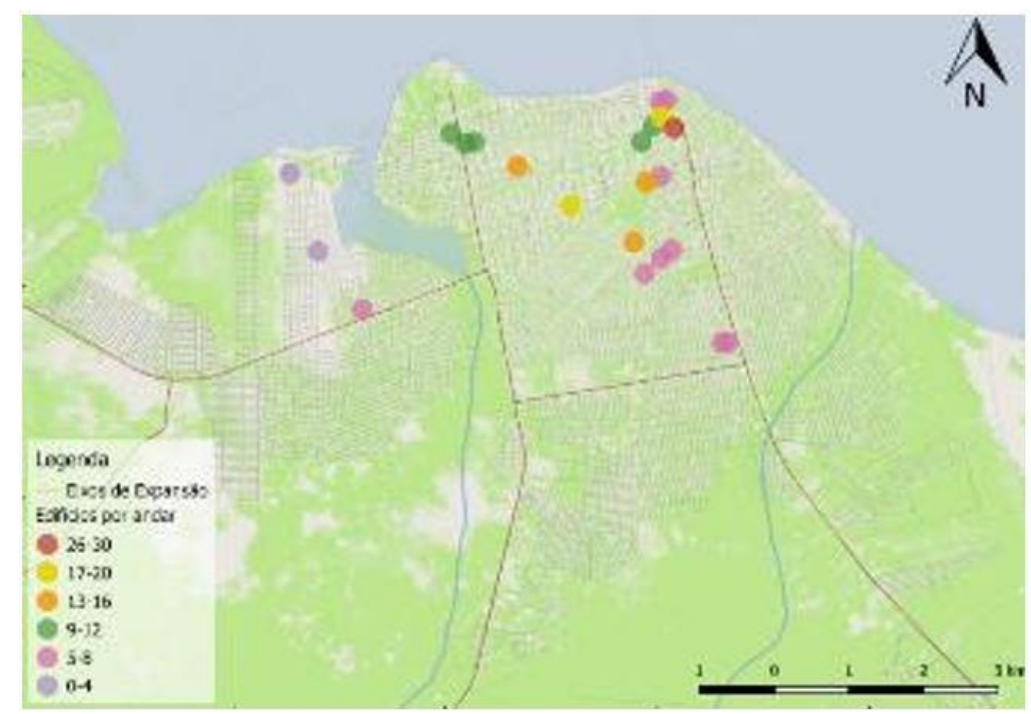

Figura 11 - Processo de verticalização da cidade. Fonte: Elaborada pelos autores com base na pesquisa de campo (2017) e no Google Earth (2017). 


\section{Considerações finais}

A cidade da produção disputa o território com os códigos espaciais de outros períodos e altera os padrões de apropriação espacial do território que sempre existiram na região sem compreender a sua resiliência. A implosão da cidade ribeirinha tem se justificado na produção da metrópole - da cidade que drena e controla o território circundante, difunde novos valores e estabelece a hegemonia do sistema econômico capitalista. Verticalização e produção de habitação em massa (3.500 unidades) são símbolos do novo urbano, que já chega obsoleto e míope às oportunidades que séculos (e mesmo milênios) de evolução têm a ensinar a respeito de como uma civilização pode perdurar em um contexto de floresta.

Contudo, sob a visão imediatista, destruir a floresta e seu povo tem sido o mais fácil fazer. A incapacidade de resistir às determinações econômicas e a concentração dos benefícios da transformação nas mãos de poucos atores políticos e econômicos precipitam a ruptura do processo de amálgama de matrizes que vinha ocorrendo desde a colonização portuguesa, o qual, se fosse mantido e melhorado com contribuições tecnológicas e incentivos, poderia evoluir no sentido do florescimento do que Monte-Mór (2015) chamou de utopia do urbano-natural. Nessa perspectiva, não seria possível recriar a metrópole do século XX em Santarém, mas reconhecer a importância da coexistência e da diferença como pilar da criação da metrópole do século XXI. Um espaço em que o respeito à diferença seria inerente ao direito ao urbano, por meio da compreensão tácita que a extensão do urbano deve corresponder à naturalização extensiva do território e da cidade.

As análises morfológicas apresentadas ao longo do texto revelaram o quanto as áreas originárias de matrizes mais tradicionais apresentam arranjos espaciais mais resilientes, que melhor apoiam as condições de vida da população herdeira de diversas matrizes culturais, mas economicamente excluída do mercado formal, em contraposição às áreas da cidade de Santarém que derivam de processos recentes (infraestrutura logística, programas habitacionais e verticalização). Apesar de as políticas públicas municipais não reconhecerem os atributos positivos dos arranjos vernaculares e caboclos e focarem apenas nas áreas consideradas formais, a análise dos recortes indica que a força da cidade está exatamente na diversidade, multifuncionalidade e escala humana herdadas de outras épocas. Atualmente, poder encontrar \manter áreas tradicionais na área urbana equivale a garantir áreas verdes, rios com potenciais de apropriação real pela população, permeabilidade do solo, microclima local ameno e suporte a um modo de vida que sempre retirou sustento da biodiversidade e que difere das manifestações clássicas das periferias de metrópoles brasileiras.

A mudança de paradigma é chave para o avanço da fase do urbano-industrial em direção à utopia do urbano-natural e demanda a capacidade de enraizar o desenvolvimento, dissociá-lo do mero crescimento econômico e da prática de dominação de pessoas e da natureza. Nessa perspectiva, os grupos sociais vistos com grande desvantagem hoje são reposicionados como portadores de soluções para um futuro possível, que, para ser mesmo possível, certamente não poderá ser determinado por um modo de produção que dissocia pessoas, águas e vegetação do solo/sítio que ocupam.

\section{Agradecimentos}

As autoras agradecem o apoio da Bolsa da Estudos da Capes e de Produtividade e Pesquisa do CNPq.

\section{Referências}

Araújo, T. B. (2000). A experiência de planejamento regional no Brasil. In T. B. Araújo (Eds.), Ensaios sobre o desenvolvimento brasileiro: heranças e urgências (pp. 17-24). Rio de Janeiro: Revan.

Becker, B. (1998). Amazônia. São Paulo: Ática.

Becker, B. (2013). A urbe amazônida: a floresta e a cidade. Rio de Janeiro: Garamond Universitária. 
Boff, L. (2011, 1 de novembro). Bem-vindo ao Antropoceno. Planeta. Recuperado em 10 de agosto de 2017, de http://www.revistaplaneta.com.br/bem-vindo-ao-antropoceno/

Brasil. Ministério do Meio Ambiente - MMA. (2015). Geocatálogo: agosto de 2015. Imagem digital de satélite. Recuperado em 20 de junho de 2016, de http://geocatalogo.mma.gov.br/

Brenner, N., \& Schmid, C. (2015). Combat, caricature \& critique in the study of planetary urbanization. Switzerland: ETH Zurich. Recuperado em 10 de maio de 2017, de http://www.soziologie.arch.ethz.ch/_DATA/90/BrennerSchmid2.pdf

Cardoso, A. C., \& Ventura, R., No. (2013). A evolução urbana de Belém: trajetórias de ambiguidades e conflitos socioambientais. Cadernos Metrópole, 15(29), 55-75.

Cardoso, A. C., Gomes, T. V., \& Melo, A. C. C. (2017). Tracking variants of urbanisation in the eastern Amazonian region through the spatial transformation patterns in six cities of Pará, Brazil. Trialog Journal, 3(122), $19-23$.

Conzen, M. P. (2009). How cities internalize their former urban fringes: a cross-cultural comparison. Urban Morphology, 13, 29-54.

Conzen, M. R. G. (1960). Alnwick, Northumberland: a study in town-plan analysis (Institute of British Geographers Publication, No. 27). London: George Philip.

Conzen, M. R. G. (1988). Morphogenesis, morphological regions and secular human agency in the historic townscape, as exemplified by Ludlow. In D. Denecke, \& G. Shaw (Eds.), Urban historical geography (pp. 255-261). Cambridge: Cambridge University Press.

Correa, R. L. (1987). A periodização da rede urbana da Amazônia. Revista Brasileira de Geografia, 49(3), 39-68.

Costa, T. (2014). Santarém: mudanças e permanências na relação cidade-rio na Amazônia. Belém: NAEA.

Gimmler, M., No., \& Costa, S. (2016). Como compreender as cidades? Revista de Morfologia Urbana, 4(2), $115-117$.

Gonçalves, C. (2017). Regiões, cidades e comunidades resilientes: novos princípios de desenvolvimento. urbe. Revista Brasileira de Gestão Urbana, 9(2), 371-385. http://dx.doi.org/10.1590/2175-3369.009.002.ao15.

Google Earth. (2017). Vista aérea do município de Santarém. Recuperado em 27 de agosto de 2017, de https://www.google.com/earth/

Hardt, M., \& Negri, A. (2004). Império. Rio de Janeiro: Record.

Hardt, M., \& Negri, A. (2016). Bem estar comum. Rio de Janeiro: Record.

Harvey, D. (2011). O enigma do capital: e as crises do capitalismo. São Paulo: Boitempo.

Heckenberger, M. (2005). The ecology of power: culture, place and personhood in Southern Amazon. London: Routledge.

Heckenberger, M. (2016). As cidades perdidas da Amazônia: a floresta tropical amazônica não é tão selvagem quanto parece. Scientific American Brasil. Recuperado em 14 de agosto de 2017, de

http://www2.uol.com.br/sciam/ reportagens/as_cidades_perdidas_da_amazonia.html

Lamas, J. (2004). Morfologia urbana e desenho da cidade. Lisboa: Ed. Fundação Calouste Gulbenkian.

Lefebvre, H. (1999). A revolução urbana. Belo Horizonte: Editora UFMG.

Lefebvre, H. (2008). Espaço e política. Belo Horizonte: Editora UFMG.

Loureiro, V. (2002). Amazônia: uma história de perdas e danos, um futuro a (re)construir. In: Revista. Estudos Avançados, 16(45), 107-121. http://dx.doi.org/10.1590/S0103-40142002000200008.

Monte-Mór, R. (1994). Urbanização extensiva e lógicas de povoamento: um olhar ambiental. In M. Santos, M. A. Souza, \& M. L. Silveira (Eds.), Território, globalização e fragmentação (1. ed., pp. 169-181). São Paulo: Hucitec/Anpur. 
Monte-Mór, R. (2006). 0 que é o urbano, no mundo contemporâneo. Revista Paranaense de Desenvolvimento, 2(111), 9-18.

Monte-Mór, R. (2014). Extended urbanization and settlemente patterns: an environmental approach. In N. Brenner (Ed.), Implosion/explosion: towards a study of planetary urbanization (1. ed., pp. 109-120). Berlin: Jovis.

Monte-Mór, R. (2015). Urbanização, sustentabilidade, desenvolvimento: complexidades e diversidades contemporâneas na produção urbano. In G. Costa, H. Costa, \& R. Monte-Mór (Eds.), Teorias e práticas urbanas: condições para a sociedade urbana (11. ed., pp. 55-70). Belo Horizonte: C/Arte.

Moudon, A. V. (1997). Urban morphology as an emerging interdisciplinary field. Journal of the International Seminar on Urban Form, 1(1), 3-10.

Muniz, P. (1904). Patrimônios dos conselhos municipaes do Estado do Pará. Lisboa: Aillaud \& Cia.

Muratori, S. (1963). Architettura e civiltà in crisi. Roma: Centro Studi di Storia Urbanistica.

Muratori, S. (1967). Civilità e território. Roma: Centro Studi di Storia Urbanistica.

Neves, E. (2015, 4 de dezembro). A cidade de todos os tempos. National Geographic.

Oliveira, V. (2018). Diferentes abordagens em morfologia urbana: contributos luso-brasileiros. E-book. Recuperado em 10 de maio de 2018, de www.vitoroliveira.fe.up.pt

Pará. (2012, 18 de janeiro). Lei complementar nº 79, de 17 de janeiro de 2012. Estabelece a criação da Região Metropolitana de Santarém. Belém: Diário Oficial do Estado do Pará, seção 1.

Pereira, J. (2016). Indígenas na metrópole: lutas multiétnicas e identidade coletiva na cidade de Manaus (AM). Belém: Faculdade de Arquitetura e Urbanismo, Universidade Federal do Pará. Palestra.

Roosevelt, A. (1992). Arqueologia Amazônica. In M. Carneiro da Cunha (Ed.), História dos índios no Brasil. São Paulo: Companhia das Letras.

Roosevelt, A. (2009). A historical memoir of archaeological research in Brazil (1981-2007). Boletim do Museu Paraense Emílio Goeldi, 4(1), 155-170. http://dx.doi.org/10.1590/S1981-81222009000100013.

Santarém. Prefeitura Municipal. (2015). Base cartográfica (sistema de ruas e topografia). Arquivo digital cedido aos autores em fevereiro de 2016.

Soja, E. (2000). Postmetropolis: critical studies of cities and regions. Oxford: Backwell.

Tavares, H. M. (2001). Políticas de desenvolvimento regional nos países do "centro" e no Brasil. Cadernos IPPUR, 15(2), 229-248.

Ventura, R. S., No. (2012). Circuito Imobiliário e a cidade: o espaço intra-urbano de Belém entre alianças de classes e dinâmicas de acumulação (Dissertação de mestrado). Programa de Pós-graduação em Arquitetura e Urbanismo, Universidade Federal do Pará, Belém.

Weimer, G. (2012). Arquitetura popular brasileira. São Paulo: Martins Fontes.

Weimer, G. (2014). Inter-relações afro-brasileiras na arquitetura. Porto Alegre: EDIPUCRS.

\section{Editor: Rodrigo Firmino}

Recebido: Nov. 24, 2017

Aprovado: Jun. 06, 2018 